\section{Self-perception and popular practices of oral health among black slave descendants elderly women in Brazil}

\author{
Autopercepção e práticas de saúde bucal entre idosas negras \\ descendentes de escravos no Brasil \\ Autopercepción y prácticas de salud bucal entre las ancianas \\ negras descendientes de esclavos en Brasil
}

\begin{abstract}
Objective: To investigate the perception and oral health practices among older quilombola women (black population group, descendants of slaves in Brazil). Methods: Qualitative research with elderly women living in a rural community formed by descendants of slaves in Brazil. The study was performed through a semi-structured interview with nine of the rural community residents and following content analysis of the narratives. Results: All elderly women are edentulous (partially or totally) and dental problems that led them to use natural means of pain relief were identified. With the analysis of the transcripts, three main categories emerged: the elderly of Quilombola Rural Community Julia Mulata and edentulism; self-perceived oral health of older women of the Quilombola Rural Community Julia Mulata; Popular practices used in the presence of health problems. Conclusion: Quilombola elderly consider the loss of teeth as natural aging; they present life stories linked to dental problems; seek to solve their dental problems with the use of traditional folk therapies.
\end{abstract}

Keywords: Dental Care; Aged; Oral Health; Self-Perception; Medical Anthropology

\section{Resumo}

Objetivo: Investigar as práticas de percepção e saúde bucal entre as mulheres quilombolas idosas (grupo da população negra, descendentes de escravos no Brasil). Métodos: Pesquisa qualitativa com mulheres idosas que vivem em uma comunidade rural formada por descendentes de escravos no Brasil. Estudo realizado por meio de entrevista semiestruturada com nove moradoras da comunidade e posterior análise de conteúdo das narrativas. Resultados: Todas as mulheres idosas são desdentadas (parcialmente ou totalmente) e identificaram problemas dentários que as levaram a usar meios naturais de alívio da dor. Com a análise das transcrições, surgiram três categorias principais: as idosas da Comunidade Rural Quilombola Julia Mulata e o edentulismo; autopercepção da saúde bucal das mulheres idosa da Comunidade Rural Quilombola Julia Mulata; Práticas populares utilizadas na presença de problemas de saúde. Conclusão: Idosos quilombolas consideram a perda de dentes como envelhecimento natural; apresentam histórias de vida ligadas a problemas dentários; procuram resolver os seus problemas dentais com o uso de terapias populares tradicionais.

Palavras-chave: Cuidados Dentários; Idoso; Saúde Bucal; Autopercepção; Antropologia Médica

Cite as: Souza MFNS, Sandes LFF, Araújo AMB, Freitas DA. Self-perception and popular practices of oral health among black slave descendants elderly women in Brazil. Rev Bras Med Fam Comunidade. 2018;13(40):1-10. http://dx.doi.org/10.5712/rbmfc13(40)1697
Maria Fernanda Neves Silveira de Souza Luiza Fernandes Fonseca Sandes Amanda Miranda Brito Araújo Daniel Antunes Freitas

Universidade Estadual de Montes Claros. Montes Claros, MG, Brasil. souza.mfernanda@gmail.com (Corresponding author); luizaffsandes@gmail.com; amandambaraujo@gmail.com; danielmestradounincor@yahoo.com

\section{Funding:} none declared. Ethical approval: 3057/11 (UNIMONTES), approved on 11/10/2011.

Conflict of interest: none declared.

Provenance and peer review: peer reviewed. Received: 02/22/2018. Accepted: 01/06/2019. 


\section{Resumen}

Objetivo: Investigar la percepción y las prácticas de salud oral entre las mujeres quilombolas mayores (grupo de población negra, descendientes de esclavos en Brasil). Métodos: Investigación cualitativa con ancianas que viven en una comunidad rural formada por descendientes de esclavos en Brasil. Resultados: Todas las mujeres de edad avanzada son desdentadas (parcial o totalmente) e identificaron problemas dentales que las llevaron a utilizar medios naturales para aliviar el dolor. Con el análisis de las transcripciones, surgieron tres categorías principales: la comunidad rural de mujeres ancianas Julia Mulata y edentulismo; autopercepción de la salud oral de las mujeres mayores de la Comunidad Rural Quilombola Julia Mulata; Prácticas populares utilizadas en presencia de problemas de salud. Conclusión: Ancianos quilombolas consideran la pérdida de dientes como envejecimiento natural; presentan historias de vida relacionadas con problemas dentales; tratan de resolver sus problemas dentales con el uso de terapias populares tradicionales.

Palabras clave: Atención Odontológica; Anciano; Salud Bucal; Autopercepción; Antropología Médica

\section{Introduction}

Global population, as well as Brazilian, has been facing transformation regarding increase in the number of elderly people. There was a large growth of the elderly population aged 60 or more ${ }^{1}$ among Brazilians, following same standards as in other countries, such as Great Britain, which will be composed by $25 \%$ of people aged 65 years or more until the year $2043 .^{2}$

However, this fact puts Brazil facing a problem regarding the lack of structure that it has in order to support emerging demands, since individuals aged 60 or more utilize much more the health system than those of younger age..$^{3,4}$

Oral health is intimately linked with general health, covering several preventable dental diseases that could be avoided simply with an adequate oral hygiene. High quality oral health should be guaranteed to all population groups, regardless of their age. However, access to oral health by older people is a global issue, aggravated by common old age problems, such as immobility, dementia, stroke and fragility. ${ }^{2}$

Oral health also constitutes a problem that, so far, has not found adequate answer in the Brazilian health system. ${ }^{4}$ Oral health of elderly has been neglected when it should be given special attention, since it operates as an integrated part of general health and primary care. This lack is demonstrated by insufficient programs focused on elderly and unreliable epidemiological situation, ${ }^{5}$ thus, implementation of comprehensive health services is extremely required for elderly groups.

Rural communities typically do not seek medical help due unawareness about a preventable dental diseases or difficult access to primary healthcare services. Compared to urban areas, rural regions have lower rates of oral hygiene, primarily because they use inexpensive and traditional methods of dental cleaning, such as chewing sticks and charcoal. " "Quilombolas" is the official name of Brazilian rural communities that are formed by black people descendants of slaves, who were brought from Africa to Brazil in colonial period. People who live in these communities are known as Quilombolas. Health issues of Quilombo populations are characterized by a reality that involves invisibility and inequality. ${ }^{7}$ Studies clearly show the serious situation faced by Quilombo rural communities regarding easier access and better health care conditions. ${ }^{7,8}$

Studies on oral health of Quilombolas are still scarce; however, in addition to promoting thoughts on the quality of life of this population, it can support measures and public policies priorities to confront basic 
problems and result in improved access to dental treatment. This study aimed to comprehend experienced perceptions, problems and usual practices related to oral health among elderly women residing in a Quilombola Rural Community in the North of Minas Gerais, Brazil.

\section{Methods}

This study was based on a descriptive research, ${ }^{9}$ constructed on the qualitative approach. ${ }^{10}$ The study was developed in the Quilombola Rural Community Julia Mulata, located in North of state of Minas Gerais, Brazil. It is a rather poor region, in both economic and social point of view. The population of the rural community Julia Mulata is approximately 160 residents living in 23 houses, in an exiguous space of 18 hectares. The habitations do not have adequate sanitary conditions, such as sewage and treated water, and are made of clay. The Community is located at a $68 \mathrm{~km}$ distance of the nearest urban area; entrance is through a narrow dirt road, in poor maintenance conditions, hampering its access.

There is no daily transport between this Quilombola Community and the city; only once a week, a shuttle transports residents in need. There is no Health Unit; doctor and nurse visit the area only once a month, the community does not receive dental care. This population does not have access to clean water and no sewage system. The consumed water comes from a pond whose contamination has been proven by experts from the Ministry of Health of Brazil. Abuse of alcohol and smoking are common, including among children and adolescents. A great percentage of the men when reach adulthood, migrate to urban centers to look for employment. Aside from homes where there are women who receive social pension, all other families are assisted by government social program of income increase. In the rural community Julia Mulata, there are no men over the age of 60 , only women.

All the older women who live there, a total of nine, participated in this study. Six of the women interviewed live alone and three live with relatives; all of them reported that the financial resources they receive from retirement represent the main financial resource of their families. Of the nine elderly women interviewed, seven are completely edentulous and two partially. During the interviews, five of the interviewees said they lost all their teeth when they were still young.

To allow the narrative to approach the substantiality of the answers and details regarding the participant's point of view, ${ }^{11}$ a semi-structured interview was used as a research instrument. To meet the objectives proposed by the study, the interview was presented with open questions, easy to understand and popular language in order to be understood by the interviewed public. The script presented questions that dealt with oral health conditions, oral health history and popular health practices common to that community. The interviews were conducted individually in the elderly women houses and interviewees were identified by increasing numbers following the order of the interviews. Furthermore, the interviews had an average duration of 23 minutes.

The interviews were recorded, the material was fully transcribed and, after thorough and careful reading, then allocated into three categories for analysis and discussion of the results; being, "the elderly women of the Quilombola Rural Community Julia Mulata and Edentulism"; "Self-perceived oral health of older Quilombola Rural Community Julia Mulata"; "Popular practices used in dealing with oral health problems." The results of the interviews were examined from the perspective of content analysis. 
The research complied with the ethical criteria established by Resolution 466/12 of the National Health Council of Brazil; it was approved by the Ethics Committee of the State University of Montes Claros under the protocol number 3057.

\section{Results}

All Quilombola elderly women participating in the study reported being partially or totally edentulous.

\section{The elderly women of the Quilombola Rural Community Quilombola Rural Community Julia Mulata and Edentulism}

When reporting on aging and tooth loss, most answered affirmatively; as if there is a cause and effect relationship between old age and tooth loss: Yes, when we grow older we lose teeth; I say this because I have lost all my teeth [...] (Interview 3). Every old person will lose their teeth, is not it? It has to fall out because old person's teeth get awful... (Interview 4) Aged ones lose all of their teeth because old person's teeth breaks easily [ [...] ] (Interview 6).

Removing teeth is seen in one of the reports, as the most efficient form of ending discomforts that arise in oral cavity: I only have four teeth and they bother me. I want to go to the dentist to extract them [...] (Interview 2).

An elderly relates good oral health conditions with economic situation: Every old person will lose their teeth. The teeth decay in old age. Only rich people can keep the teeth in the mouth. Poor old people lose their teeth (Interview 5).

\section{Self-perceived oral health of elderly at Quilombola Rural Community Julia Mulata}

When asked if they knew or have heard about any dental problem, it was observed reporting of unfavorable prosthetics conditions: I use denture; when it breaks hurts my mouth. I think the mouth only gets diseases in teeth (Interview 6).

Among the speeches, infection and bad breath were also cited: I think it can get problems in the mouth if the tooth gets bad. I do not have teeth. A person who does not take care of the tooth has bad breath. So, for those who does not care, everything goes bad [...] (Interview 3).

Other statements show the tooth widely destroyed as a problem of the mouth: I had a very rotten tooth in my mouth, it bothered me (Interview 8). I asked for the dentist to extract my teeth so keep it from getting hurt (Interview 4).

But also, when inquired about oral health problems, some of the women said they did know how to explain, another preferred not to talk, and other justified ignoring the fact due to not knowing how to read and write: That I do not know (Interview 1). I do not know anything about it and l'd rather not speak (Interview 2). Of the mouth? I do not know, do not know how to read or talk. I did not study and I do not even know how to talk (Interview 5).

Even with the total loss of teeth, some people evaluate the oral health as good: It is not bad; I do not feel anything bad; I do not have teeth. I am not healthy enough to work [...] (Interview 1). The health status of my mouth is great because I lost my teeth. The mouth is bad when the teeth hurt (Interview 4). 
Given this scenario, it is observed that, for the Quilombola older women of Julia Mulata, losing their teeth is not a problem related to dentition or oral health, for them it is a natural event. The idea of extraction as a solution to the damaged tooth is very strong: The health of my mouth is not good. I have broken teeth and I want the dentist to extract them [...] (Interview 2).

Oral condition interferes with quality of life; the following statement portrays this condition: Of my mouth? My mouth is good; my teeth hurt. I cannot eat or drink cold or hot things because my teeth get hurt (Interview 3).

\section{Popular practices used in dealing with oral health problems}

When inquiring elderly as they took care of oral health, some reported poor hygiene, using only water and/or ashes from gray wood stove: I just wash it with water [...] (Interview 1). I wash the mouth with water and rub my hand in the gum, that's how I take care of it (Interview 3). I only splash some water. When the teeth are dirty I use ash from wood stove (Interview 9).

Brushing was a dental care practice mentioned, along with use of tobacco and ash in order to perform cleansing of teeth: Oh, I use a brush to clean these four teeth I have. I am careless; when I was young, I brushed too, now I do not brush every day, no (Interview 2). I take care of my mouth's health, I chew tobacco (Interview 4). I clean my teeth with tobacco, I rub tobacco and ashes (Interview 8).

Pain is one of the greatest symptomatic damage that affects the mouth. It is the main cause of demand for dental services in Brazil. ${ }^{12}$ In the reports of Quilombola elderly women it was possible to note that, against dental pain, most resorted to popular practices: I put burnt tobacco in the broken tooth. My mother used to burn coconut and put it in broken teeth (Interview 2). I cleansed with bush plants remedies (Interview 4). I used to put an acid of a plant taken from the forest; the acid broke the tooth and the pain eased (Interview 9).

\section{Discussion}

Universally, poor access to dental services leads to larger rates in incidences of dental cavities, periodontal disease, tooth decay, oral cancer and xerostomia. ${ }^{11}$ In Brazil, we can see a poor oral health among elderly, with many citizens without teeth and few people free of dental and periodontal problems. . $5,13,14^{2}$ On this, Quilombola elderly women are not exempt; all reported to be partially or fully edentulous. Overall, difficulty chewing, bad breath and embarrassment of not having healthy teeth are factors that greatly affect the quality of life of edentulous patients. ${ }^{5,14}$

Based on information and knowledge built, influenced by previous experience and social and cultural norms, self-perceived health is the interpretation that person makes of their health and illness experiences in context of their own daily life. ${ }^{15}$ In dentistry, the evaluation of self-perceived oral health in an important routine basis is that encourages adoption of healthy behaviors, and yet allow community participation in policy formulation and social decisions, in addition to making possible a more effective approach to the subject by health professionals. ${ }^{13,16,17}$ Self-assessment indicators should be used as complementary tools to identify the needs of the studied population, with the role of aid in diagnosis, treatment and collection of subsidies for necessary public health interventions, regarding the identified problems. 
Reports show that older naturally accept the partial or total loss of teeth. Edentulism is still accepted by many as a natural phenomenon of aging. However, it is known that this fact is result of lack of information, prevention and consequently care with oral hygiene, which should be practiced from childhood to adulthood, in order to keep all teeth to older ages. ${ }^{18,19}$ It is noticed that elderly are used to tooth loss because this procedure is taken, in most cases, as the only solution to the problems that arise in the mouth, especially in pain relief.

It is observed that, in the case of interviewees listed in this study, all of them are partially or totally edentulous, perhaps this condition leads elderly to infer that by not having any teeth left, there is no need to properly perform hygiene in their mouth, which can lead to health problems such as thrush, halitosis and oral burning. ${ }^{16}$ One interviewee, despite not being able to elucidate the mouth diseases she knew, by her own experience, talked about the discomfort that a poorly adapted prosthesis can cause. This report confirms the results of research on self-perceived oral health and impact on the elderly's quality of life, that when discussing relative dimensions of the impact of use of prostheses, presence of discomfort was the most prevalent. ${ }^{5,14}$

Traditional knowledge and customs inherited from ancestors are perpetuated through generations and guarantee unique experiences, perceptions, realities and stories that the Quilombolas live. ${ }^{20}$ This culture produced within the black communities is still perpetuated inside the Quilombos and these practices are not connected to formal health services. ${ }^{17,21}$ It is important to reassure that traditional practices, regarding health, is a way to seek treatment for each specific disease or to prevent harm and ensure good health. ${ }^{22}$ In Brazil, it is common the use of plants for medicinal purposes, but in relation to oral health, it is still remotely used..$^{23}$

The reports clearly demonstrate that there is a lack in relation to guidance and education on oral hygiene among Quilombola elderly women; although there is a great amount of literature specializing in this respect, the appropriate actions are not routine in the surveyed population. 5,14

Obviously, indications for use of the substances mentioned by interviewees for temporary or permanent relief of dental pain source are not found in current scientific studies of Dentistry. Although reports on the use of plant acid for this purpose are unusual, the use of homemade remedies is widespread in Brazil. ${ }^{23,24}$

Regarding the limitations of the study, the possible differences among regions in Brazil, due to vast dimensions of the country and distribution of so many ethnic communities, the results could evidence distinct realities if the survey had been conducted in other communities.

Edentulism is, worldwide, related to older age. Especially in rural or remote areas, the poor access to health services and education aggravates the number of elderly who lose their teeth throughout their life. ${ }^{6,25}$ In the United Kingdom, there were $15 \%$ of people aged $65-74$ years that were edentulous, in Sweden, Denmark and Finland, by 1990 the rate of edentulism among elderly over 75 years old was, respectively, $27 \%, 45 \%$ and $58 \%{ }^{26}$

Scientific literature demonstrates a large difference between oral health status among minority and majority groups in many societies of the globe. In United States, Hispanics, farmworkers, and African Americans have lower levels of oral health and greater dental health needs. ${ }^{27}$ In Australia, among some isolated communities, such as Aboriginal and rural populations, there is deficient oral health and lack of dental health awareness, resulting in higher edentulism rates, denture need and dental decay. ${ }^{25}$ Rural African populations, often associated with poverty and lower education levels, have higher rates of dental treatment needs, inadequate oral health and poor access to dental care services. ${ }^{6}$ 
A widely destroyed tooth is a mouth disease closely associated with poor hygiene and absence of regular dentist appointments, and, when installed, have as primary therapy the extraction of the referred decayed tooth. Even though recent days technologies allow other conservative therapies to patients who have easy access and financial conditions to enable more advanced treatment. ${ }^{16,19,20}$ As it is known in recent days, caring for oral hygiene is important to prevent partial or total teeth loss ${ }^{28}$

Studies show that Brazilians aged over 65 have lost more than $90 \%$ of their teeth ${ }^{16,17}$, these results collaborate with the resigned thought of Quilombola elderly population regarding tooth loss. In Brazil, black population is more subjected to tooth extractions than white, even if being in same clinical condition, which comes to present a comparison of $25.5 \%$ for teeth extractions among blacks against $16.2 \%$ for extractions among whites respectively. ${ }^{28,29}$ Even in countries that develop health programs for elderly, the main reason that they do not seek dental services is absence of perception about their own needs. ${ }^{22}$

As has been reported by one of the older women, studies claim that low socioeconomic status significantly increases edentulous condition, ${ }^{30}$ the better the socioeconomic level less dental damage the individual will present. ${ }^{24}$ All elderly women declared themselves black and illiterate; that fact draws attention to the focus of this study on oral health, since the literature indicates the worst oral health conditions in people with lower education levels. ${ }^{4,5,15,16}$ Disinformation and low level of education widely influence on this self-assessment, in which respondents claim good oral health conditions when clinical tests indicate dental problems. In this case, it is assumed that unawareness of diseases that can affect oral region favors the non-perception of problems. ${ }^{13,15,31}$

The anthropological aspect of health and analysis of cultural meaning and representation of pain is an interesting topic to be pointed out, regarding the testimonies of these Quilombola elderly women. Anthropology of health is a quite recent area still under development, especially in Brazil. ${ }^{32}$ Through anthropological spectrum of healthcare it is possible to understand and visualize the myriad of meanings that illness and health have, under influence of cultural, ethnic, religiousness and social aspects of each and every society of the globe. ${ }^{32}$ It is fundamental for healthcare professionals working with rural and indigenous groups, such as Quilombolas, the knowledge of cultural aspects of that community, their understanding of health and the most common therapeutic practices among them. ${ }^{33}$ The pain itself is a subject feeling, that can only be experienced by the patient, but it carries a huge social representation, through human suffering, that is expressed by personal statements. ${ }^{32}$ As Quilombola women described, dental pain is one of the most common and distressing types of ache, interfering in labor activities, eating, sleeping and emotional balance. ${ }^{32}$ It is well documented the connection of higher dental pain rates with lower socioeconomic status and reduced educational levels. ${ }^{32}$

One of the elderly associated bad breath and infection with lack of treatment and dental care; her statement shows two problems that the scientific literature says are closely linked, especially relating to persistent halitosis. ${ }^{34}$

The poorly adapted prosthesis is a predisposing factor to the onset of various dental problems, such as oral lesions; traumatic ulcers, which arise due prostheses with over-extended edges and unbalanced occlusion; stomatitis; difficulties to relax; candidiasis; embarrassments; restriction on eating certain foods and social isolation, interfering with quality of life of elderly. $3,20,21$ 


\section{Implications for research in the field and practice of professionals}

This study emphasizes the relevance of oral health assessment in rural communities, such as Quilombolas, and indicates the importance of its articulation with the Primary Health Care (PHC). For rural and isolated ethnic groups, the PHC is the first, and commonly, the only health service available within the limits of their territory. Therefore, this service should be extremely complete and capable of effective prevention and early diagnosis.

Oral health should be integrated and synchronized with general health, being one important influence factor on the quality of life of people of all ages, especially elderly. Dental hygiene in primary health is an impressive instrument for prevention of bucal diseases and is an important health educational tool. This study demonstrates that many of elderly Quilombola women do not do adequate oral hygiene nor recognizes their own bucal problems, as they should do. This shows lack of an attentive PHC in the community's area and poor education on basic oral care.

Another important topic, indicated in this research, is the rather common traditional health practices among rural communities. Adoption of health care practices inherited from past generations is, until present, a significant habit for many Quilombola and other ethnic groups in Brazil and globally. Those represent a culture that exists for hundreds of years and the use of medicinal plants and sacred rituals is part of the people's identity. The PHC should be aware of all habits and cultural aspects of the population within its territory and has to balance formal medicine with traditional healing practices, so the identity of the community keeps preserved. Regarding oral health, not many traditional practices were found in this research, although it is important to recognize the importance of those practices in the life of many Quilombolas, across rural clans of the country.

Qualitative research methods are widely recognized as one of the main techniques of understanding the patient's perception of illness, through a transcultural perspective and comprehension of their social and ethnical environment. These personal statements are a slight piece of the daily life and perception of Quilombolas, concerning oral health. Those statements, extracted from real suffering experience and reports, are important material to compose a critical analysis of oral and general health aspects among rural ethnic groups in Brazil.

The implication of this study in future researches is the necessity of exploring and investigating the various aspects of PHC and of identifying the lacking areas in rural communities, such as Quilombolas. Isolated and difficult-access societies need to have a specialized health care, as they face many health access obstacles and present unique culture and epidemiology. A study conducted in Manaus, Brazil, demonstrated the great importance of the presence of Family Medicine Clinics to decrease grades of dental pain, among adolescents. The pain's intensity was proved to be enhanced in areas without PHC coverage. ${ }^{35}$ Researches involving rural communities and $\mathrm{PHC}$ are essential to development of public health policies involving those people and focusing on their specific health indicators. 


\section{Conclusions}

This study brings up an issue that, although serious and old, still seems to be far away to be resolved: the difficulties faced by Brazilians, descendants of slaves and residents of rural populations, concerning the most basic health conditions.

It is necessary that Brazilian society and the constituent authorities get involved quickly and efficiently in the strengthening of public policies that will treat ethnic groups as a health priority and inequity and will ease this rather long deficit of comprehensive health care of those remaining in Quilombos, especially for senior citizens and their oral health conditions.

\section{References}

1. Brasil. Instituto Brasileiro de Geografia e Estatística - IBGE. Ministério do Planejamento, Orçamento e Gestão. Pesquisa Nacional por Amostra de Domicílios - PNAD: síntese de indicadores 2015. Rio de Janeiro: IBGE; 2016 [cited 2017 Mar 7]. Available from: https:// biblioteca.ibge.gov.br/visualizacao/livros/liv98887.pdf

2. Fox C. Evidence summary: why is access to dental care for frail elderly people worse than for other groups? Br Dent J. 2010;208(3):11922. http://dx.doi.org/10.1038/sj.bdj.2010.103

3. Creutzberg M, Gonçalves LHT, Sobottka EA, Ojeda BS. Long-term care institutions for elders and the health system. Rev Lat Am Enferm. 2007;15(6):1144-9. http://dx.doi.org/10.1590/S0104-11692007000600014

4. Alves LC, Leite I, Machado CJ. Health profile of the elderly in Brazil: analysis of the 2003 national household sample survey using the grade of Membership method. Cad Saúde Pública. 2008;24(3):535-46. http://dx.doi.org/10.1590/S0102-311X2008000300007

5. Ferreira RC, Schwambach CW, Magalhães CS, Moreira NA. Dental care and oral hygiene practices in long-term geriatric care institutions. Ciênc Saúde Coletiva. 2011;16(4):2323-33. http://dx.doi.org/10.1590/S1413-81232011000400032

6. Ogunbodede EO, Kida IA, Madjapa HS, Amedari M, Ehizele A, Mutave R, et al. Oral Health Inequalities between Rural and Urban Populations of the African and Middle East Region. Adv Dent Res. 2015;27(1):18-25. http://dx.doi.org/10.1177/0022034515575538

7. Freitas DA, Caballero AD, Marques AS, Hernández CIV, Antunes SLNO. Health and quilombolas communities. Rev CEFAC. 2011;13(5):93743. http://dx.doi.org/10.1590/S1516-18462011005000033

8. Freitas DA, Silveira JCS, Ferreira LA, Zucchi P, Marques AS. Mulheres quilombolas: profissionais na Estratégia de Saúde da Família. Rev Esp Saúde. 2011;12(2):56-62. http://dx.doi.org/10.22421/1517-7130.2011v12n2p56

9. Trivinos ANS. Introdução à Pesquisa em Ciências Sociais - A Pesquisa Qualitativa em Educação. 4ª ed. São Paulo: Atlas; 1995.

10. Minayo MCS, org; Deslandes SF, Gomes R. Pesquisa Social: Teoria, Método e Criatividade. 23ª ed. Vozes: Petrópolis; 2004.

11. Muylaert CJ, Sarubbi Jr. V, Gallo PR, Rolim Neto ML, Reis AOA. Entrevistas narrativas: um importante recurso em pesquisa qualitativa. Rev Esc Enferm USP. 2014;48(n.spe2):193-9.

12. Brasil. Ministério da Saúde. Secretaria de Atenção à Saúde. Secretaria de Vigilância em Saúde. SB Brasil 2010: Pesquisa Nacional de Saúde Bucal: resultados principais [Internet]. Brasília: Ministério da Saúde;2012. [cited 2014 Sep 30]. Available from: http://bvsms.saude. gov.br/bvs/publicacoes/pesquisa_nacional_saude_bucal.pdf

13. Martins AMEBL, Barreto SM, Silveira M, Santa-rosa TTA, Pereira RD. Self-perceived oral health among Brazilian elderly individuals. Rev Saúde Pública. 2010;44(5):912-22. http://dx.doi.org/10.1590/S0034-89102010005000028

14. Simões ACA, Carvalho DM. The reality of the oral/dental health of the elderly in the Brazilian Southeast. Ciênc Saúde Coletiva. 2011;1(6):2975-82. http://dx.doi.org/10.1590/S1413-81232011000600035

15. Bulgarelli AF, Manço ARX. A population of elderly and their satisfaction with their oral health. Ciênc Saúde Coletiva. 2008;13(4):1165-74. http://dx.doi.org/10.1590/S1413-81232008000400012 
16. Benedetti TRB, Mello ALSF, Gonçalves LHT. Idosos de Florianópolis: autopercepção das condições de saúde bucal e utilização de serviços odontológicos. Ciênc Saúde Coletiva. 2007;12(6):1683-90. http://dx.doi.org/10.1590/S1413-81232007000600029

17. Unfer B, Brauni K, Silva CP, Pereira Filho LD. Self-perception of the loss of teeth among the elderly. Interface (Botucatu). 2006;10(19):21726. http://dx.doi.org/10.1590/S1414-32832006000100015

18. Nguyen TC, Witter DJ, Bronkhorst EM, Truong NB, Creugers NH. Oral health status of adults in Southern Vietnam - a cross-sectional epidemiological study. BMC Oral Health. 2010;10:2. https://dx.doi.org/10.1186\%2F1472-6831-10-2

19. Uguru NP, Akaji EA, Ndiokwelu E, Uguru CC. Assessing health workers knowledge on the determinants of health: a study in Enugu Nigeria. Niger J Med. 2012;21(1):48-52.

20. Reis SCGB, Marcelo VC. Oral health in old age: elderly's perceptions, Goiânia, 2005. Ciênc Saúde Coletiva. 2006;11(1):191-9. http:// dx.doi.org/10.1590/S1413-81232006000100028

21. Borba AM, Macedo M. Medicinal plants used for oral health in the Santa Cruz neighborhood, Chapada dos Guimarães, Mato Grosso State, Brazil. Acta Bot Bras. 2006;20(4):771-82. http://dx.doi.org/10.1590/S0102-33062006000400003

22. Medeiros LCM, Azevedo GAV, Machado FM, Sousa SR. The popular healing practical used by prayers in the Brejinho Village, in Luiz Correia city - Piauí - Brazil. Esc Anna Nery. 2007;11(1):112-7. http://dx.doi.org/10.1590/S1414-81452007000100016

23. Oliveira EOS, Collier KFS, Mota GMF, Ely BP, Pereira FR. Plantas Medicinais Usadas pela Comunidade Kalunga do Quilombo do Engenho de Dentro em Cavalcante-GO para Tratamento de Afecções Bucais. Rev Cereus. 2010;2(2).

24. Silva MES, Villaça EL, Magalhães CS, Ferreira EF. Impact of tooth loss in quality of life. Ciênc Saúde Coletiva. 2010;15(3):841-50. http:// dx.doi.org/10.1590/S1413-81232010000300027

25. National Rural Health Alliance - LTD. [Internet]. 2017 [cited 2017 Mar 7]. Available from: http://ruralhealth.org.au

26. Peltzer K, Hewlett S, Yawson AE, Moynihan P, Preet R, Wu F, et al. Prevalence of loss of all teeth (edentulism) and associated factors in older adults in China, Ghana, India, Mexico, Russia and South Africa. Int J Environ Res Public Health. 2014;11(11):11308-24. https:// dx.doi.org/10.3390\%2Fijerph111111308

27. Castañeda H, Carrion IV, Kline N, Tyson DM. False hope: effects of social class and health policy on oral health inequalities for migrant farmworker families. Soc Sci Med. 2010;71(11):2028-37. http://dx.doi.org/10.1016/j.socscimed.2010.09.024

28. Ferreira AAA, Piuveza MG, Werner CWA, Alves MSCF. The toothache and toothloss: social representation of oral care. Ciênc Saúde Coletiva. 2006;11(1):211-8. http://dx.doi.org/10.1590/S1413-81232006000100030

29. Souza EHA, Oliveira PAP, Paegle AC, Goes PSA. Race and the use of dental health services by the elderly. Ciênc Saúde Coletiva. 2012;17(8):2063-70. http://dx.doi.org/10.1590/S1413-81232012000800017

30. Silva MEA, Rosa PCF, Neves ACC, Rode SM. Prosthetics needs of the Quilombola Population of Santo Antonio Guaporé, Rondônia. Braz Dent Sci. 2011;14(1-2):62-6.

31. Haikall DSA, Paula AMB, Martins AMEBL, Moreira AN, Ferreira EF. Self-perception of oral health and impact on quality of life among the elderly: a quantitative-qualitative approach. Ciênc Saúde Coletiva. 2011;16(7):3317-29. http://dx.doi.org/10.1590/S141381232011000800031

32. Lucas SD, Mattos FF, Melo JAC, Vasconcelos M, Abreu MHNG, Ferreira NE. Uso de metáforas para expressar a dor de dente: um estudo na área de antropologia da saúde. Ciênc Saúde Coletiva.2014;19(6):1933-42. http://dx.doi.org/10.1590/1413-81232014196.05022013

33. Langdon EJ, Wiik FB. Anthropology, Health and IIIness: an Introduction to the Concept of Culture Applied to the Health Sciences. Rev Lat Am Enferm. 2010;18(3):459-66. http://dx.doi.org/10.1590/S0104-11692010000300023

34. Silva DD, Held RB, Torres SVS, Sousa MLR, Neri AL, Antunes JLF. Self-perceived oral health and associated factors among the elderly in Campinas, Southeastern Brazil, 2008-2009. Rev Saúde Pública. 2011;45(6):1145-53. http://dx.doi.org/10.1590/S003489102011005000068

35. Carvalho JC, Rebelo MAB, Vettore MV. Dor dental nos últimos 3 meses em adolescentes e Estratégia Saúde da Família: a comparação entre duas áreas com abordagens diferentes de atenção em saúde bucal. Ciênc Saúde Coletiva. 2011;16(10):4107-14. http://dx.doi. org/10.1590/S1413-81232011001100016 